\title{
Are Road Crossings Fragmenting Populations of Clinch Dace?
}

\author{
Rebecca M. Bourquin ${ }^{1}$, Donald J. Orth ${ }^{1, *}$, Eric M. Hallerman ${ }^{1}$, and \\ Dean F. Stauffer ${ }^{1}$
}

\begin{abstract}
Chrosomus sp. cf. saylori (Clinch Dace) is a newly recognized species of minnow with a restricted distribution in southwestern Virginia. We analyzed genetic variation and abundance at paired sites above and below road crossings. Road crossings did not have a strong effect on presence, abundance, or genetic differentiation of Clinch Dace. Of all sites where Clinch Dace were found, only 1 perched culvert presented a barrier to upstream migration; however, no genetic differentiation was found between collections above and below that or any other culvert. Distribution and abundance of Clinch Dace populations were not influenced by habitat variables measured at the site level. Low abundance in small headwaters, nest association, and high mobility appear to be characteristics of this species of Chrosomus.
\end{abstract}

\section{Introduction}

Habitat fragmentation in lotic systems is a serious and growing threat to fish populations worldwide (Perkin and Gido 2012). Maitland et al. (2016) showed that industrial stream crossings influenced abiotic habitat characteristics, restricted biotic connectivity, and impacted fish community structure at the whole-stream and within-stream scales in an industrializing region of boreal forest in Alberta. Barriers to upstream migration are associated with lower fish abundance at sites upstream relative to downstream sites (Briggs and Galarowicz 2013, Eisenhour and Floyd 2013, Nislow et al. 2011). For stream fish, species richness (alpha diversity) correlated more strongly with landscape alteration, and among-site diversity (beta diversity) was correlated with fragmentation and habitat size (Edge et al. 2017, Perkin et al. 2015). Road crossings can fragment fish populations through a variety of mechanisms. In particular, some culverts may become "perched" over time; that is, the bottom of the culvert can come to overhang the streambed, limiting or precluding upstream passage for fish that are not strong leapers (Fig. 1). By preventing upstream movement, barriers to movement increase likelihood of local extirpation by disturbance events. Where a disturbance event, such as a landslide or chemical spill, occurs and a population is reduced or extirpated, barriers may prevent recolonization from downstream source populations. Even if a population recovers from such an event, it likely would have reduced genetic variation, lessening adaptivity (Alo and Turner 2005, Guy et al. 2008, Morita and Yamamoto 2002, Whiteley et al. 2013).

\footnotetext{
${ }^{1}$ Department of Fish and Wildlife Conservation, Virginia Tech University, Blacksburg, VA 24060. *Corresponding author - dorth@vt.edu.
}

Manuscript Editor: Stephanie Coster 
Chrosomus sp. cf. saylori (Clinch Dace) is a currently undescribed species of minnow (Family Leuciscidae, Tan and Armbruster 2018) that was first discovered in Tazewell County, VA, in 1999 (Skelton 2007). Clinch Dace was first thought to be a disjunct population of the closely related Chrosomus saylori (C.E. Skelton) (Laurel Dace). However, meristic and morphological differences between these congeners, such as a longer anal fin base and shallower head in the Clinch Dace and differences in breeding colors, suggest that species status is warranted (White and Orth 2013). Clinch Dace occur only in scattered locations in second- and third-order streams in the Central Appalachian physiographic province in northern Russell and Tazewell counties of Virginia (Moore et al. 2018).

Streams that support Clinch Dace have a high road density and frequent road crossings, and Clinch Dace show patchy distributions within these streams, often occurring in pools downstream from road crossings (Moore et al. 2018, White and Orth 2014). Road crossings that are not obvious barriers can inhibit fish movement simply by increasing water velocities and altering habitat (Benton et al. 2008, Briggs and Galarowicz 2013, Eisenhour and Floyd 2013, Warren and Pardew 1998). It is therefore reasonable to hypothesize that road crossings in the upper Clinch River basin may further fragment Clinch Dace populations that already are fragmented by topography. Fragmentation by road crossings could affect patch occupancy and

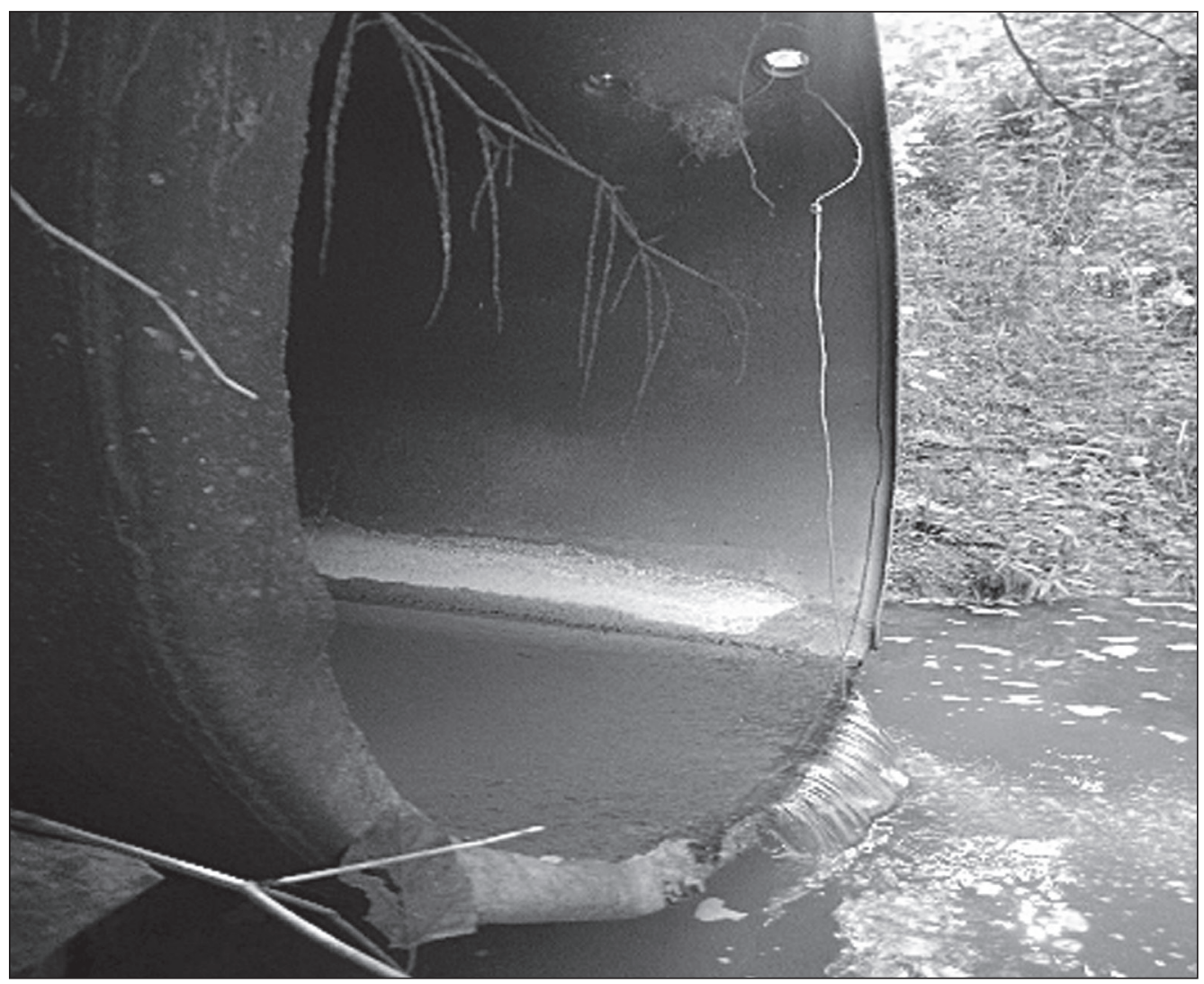

Figure 1. A perched road culvert at Hart Creek site 2. 
abundance at sites throughout the species' distribution. Alternatively, patch occupancy and population abundance could be determined largely by habitat quality or fish community structure. If demographic fragmentation is indeed taking place along a stream, then that should become evident from population genetic structure among sites within a stream. The degree of genetic differentiation has implications for the effectiveness of certain possible management actions. Translocations could lead to optimal outcrossing and the restoration of lost alleles and diversity. However, if coadapted gene complexes (combinations of alleles at different loci that come together by chance, increase the fitness of the carrier, and are maintained by selection) have arisen in populations, then outbreeding depression could result from translocations (Hallerman 2003, Templeton et al. 1986).

Traditionally, studies of the effects of habitat fragmentation on fish relied on mark-recapture studies (Benton et al. 2008, Briggs and Galarowicz 2013, Warren and Pardew 1998), which suffer from low recapture rates and typically are carried out on small, reach scales over short time-frames (Nislow et al. 2011). Genetic approaches have enhanced the sensitivity for detecting fragmentation effects (Whiteley et al. 2014). Genetic analysis also can provide insight into whether populations were historically connected before a barrier was constructed or if they were naturally isolated by distance. For instance, anthropogenic barriers to migration, rather than intrinsic limitations to vagility, structured populations of Percina rex (Jordan \& Evermann) (Roanoke Logperch; Roberts et al. 2013). Smaller populations are more susceptible to genetic drift and inbreeding depression, and genetic differentiation can take place across riverine barriers. Reduced habitat patch size and reduced population size affected Salvelinus albopunctatus (Pallas) (White-Spotted Char) populations below dams (Yamamoto et al. 2004). Genetic differentiation may increase following population fragmentation with a lack of up- or downstream migration. Such a degree of fragmentation may be informative for classifying management units for conservation, reinforcing the view that the landscape perspective that is accessible through genetic analysis is critical for understanding the effects of habitat fragmentation. Knowing the degree of genetic variation among populations is of particular interest if population augmentation is considered as a management action, as it may determine how to proceed with translocations, captive propagation, or augmentation. If populations show significant genetic divergence, then translocation may not be a viable option as it could lead to outbreeding depression.

The Virginia Department of Game and Inland Fisheries lists the Clinch Dace as a species of conservation concern, or critically imperiled. Clinch Dace populations are small and fragmented (Moore et al. 2017). Therefore, our purposes for this study were to test the hypotheses that: (1) Clinch Dace presence and abundance are determined by habitat and community factors; (2) fragmentation by barriers, such as road crossings and perched culverts, determine Clinch Dace presence and abundance; and (3) barriers affect genetic divergence of Clinch Dace. 


\section{Field-Site Description}

Fish surveys have been conducted across the putative range of Clinch Dace in Virginia by several researchers since 1999 (Moore et al. 2018). All sites selected for this study were at sites of known occurrence of Clinch Dace (center of the range was at $\left.37^{\circ} 03^{\prime} 39.59^{\prime \prime} \mathrm{N}, 81^{\circ} 50^{\prime} 31.19^{\prime \prime} \mathrm{W}\right)$ and location names were summarized in Moore et al. $(2017,2018)$.

\section{Materials and Methods}

\section{Study design}

To determine whether road crossings were barriers to upstream migration, we employed an observational study design at "sites" in streams within the known distribution of Clinch Dace (Moore et al. 2018). Except for 1 site, we sampled at road crossings to determine whether they are fragmenting Clinch Dace popu-

[PLURAL?DIDN'T YOU JUST SAY THAT ONLY A SINGLE SITE WAS NOT AT A ROAD CROSS-

ING?]

[AGAIN, WAS THEIR MORE THAN 1 SITE NOT AT A ROAD CROSSlations upstream and downstream. Whenever possible, each site consisted of 1 downstream and 1 upstream sampling unit in close proximity. In the case of sites located at road crossings, these sampling units extended upstream and downstream from a road crossing. In the case of non-road crossing comparator sites [??], there was an upstream and a downstream sampling unit. The number of sites and the number of sampling units within each site was constrained by permission to access a landowner's property, accessibility, proximity of other road crossings, and practical aspects of ability to sample effectively (e.g., the stream was not dry or converted by a beaver dam). We collected and analyzed habitat and fish community data to test the hypothesis that Clinch Dace abundance and/or presence is determined by habitat and community factors. To determine the effects of barriers on Clinch Dace populations, we used upstream and downstream sampling units in a paired experimental design. Genetic analysis contributed to achievement of this objective, as we used paired sampling units and estimates of genetic divergence to test for genetic differentiation of Clinch Dace collected from upstream and downstream sampling units.

\section{Site selection and reconnaissance}

We identified and reconnoitered $\sim 80$ potential sites using ArcGIS 10.1 shapefiles of Clinch Dace-occupied sites in Russell and Tazewell counties, VA. We measured stream width at 11 transects along each potential sampling unit, starting at the road crossing and extending $200 \mathrm{~m}$ upstream or downstream [WERE THE TRANSECTS SPACED EVENLY, I.E., 20 M APART?]. At non-crossing sites, measurements began at the downstream-most transect of the downstream sampling unit and proceeded upstream for $200 \mathrm{~m}$. If average width of the first 11 transects exceeded $5 \mathrm{~m}$, then we added more transects until the sampling distance totaled at least 40 times the average width; site lengths of $\sim 40$ times average stream width are adequate in eastern streams to characterize community and associated habitat (Klemm and Lazorchak 1995, Lyons 1992). Upstream sampling units at non-road-crossing sites [??] were measured from the midpoint (200-m mark as measured from the down-

[KLEMM

AMD

$\underline{\mathrm{LAZOR}}$

CHAK 1995

IS NOT IN

LIT CITED.

PLEASE

ADD. OR

$\underline{\text { SHOULD }}$

BELAZOR-

CHAK ET

AL. 1998?] 
stream reach) up to a 400-m mark. No [NON-ROAD-CROSSING?] sampling units exceeded $5 \mathrm{~m}$ in width, and only 1 sampling unit was less than $100 \mathrm{~m}$ in length [??].

\section{Habitat sampling}

At each transect, we ranked canopy cover as percentage of shaded stream according to the Daubenmire and Daubenmire (1968) classes and noted the presence or absence of woody debris. From these data, we derived average canopy cover in each reach by taking the midpoint of each rank for each transect and averaging across all transects in the reach. For analysis of woody debris, we calculated the proportion of transects containing woody debris for all transects in each reach.

At all road-crossing sites, we evaluated culverts or bridges as possible barriers to fish movement. We also measured culvert dimensions, the distance from the bottom of the culvert to the top of the water and to the stream bed, and length from culvert outlet to downstream hydraulic control, and photographed the crossing. Along each reach, we recorded the type of riparian buffer present, estimated the average width of that buffer, and noted the type of land use adjacent to the buffer zone. We recorded the maximum depth in the reach and took a single conductivity measurement at each site, at the downstream end.

\section{Fish sampling}

We conducted 3-pass electrofishing depletions in sampling units. We used 1 backpack Smith-Root LR 24 backpack electrofisher set to 300 volts per $3 \mathrm{~m}$ of average stream width (Kazyak 2001). We measured captured Clinch Dace for total length and cut a small fin-clip from the upper caudal fin, which we stored in $95 \%$ ethanol. In order to ensure that adequate sampling estimated total species richness, we tallied species richness as the total number of species caught during all 3 passes. We estimated population size in each sub-reach using 3-pass depletion data in Microfish 3 (Van Deventer and Platts 1989) that we standardized to $100 \mathrm{~m}$ of stream length. All fish sampling was done in accordance with Virginia Tech IACUC protocol FWC 16-188.

\section{Habitat and fish community data analysis}

Previous habitat analyses (White and Orth 2014) informed our selection of habitat variables. For each stream reach, we performed logistic regression analysis of Clinch Dace presence/absence as a function of average estimated canopy cover, conductivity, maximum depth, presence of woody debris, fish density, and fish spe-

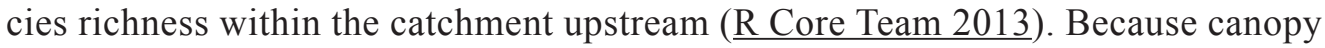
cover was recorded as ranks, we took the midpoint of each category for each transect and averaged them to give 1 value of canopy cover for each reach (Daubenmire and Daubenmire 1968).

We calculated fish density by dividing the total number of fish caught in a reach by the product of the average width and total length of that reach. We conducted quasi-Poisson regressions in R ([VERSION?]; R Core Team 2013) on Clinch Dace abundance because the data were not normal and dispersion was high at each reach as a function of average estimated canopy cover, conductivity, maximum depth, 
presence of woody debris, fish density, and fish species richness. We conducted quasi-Poisson regressions and logistic regression on Clinch Dace abundance and presence/absence and conductivity for each site $(n=15)$.

We conducted paired $t$-tests on Clinch Dace abundance on the upstream and downstream reaches of each site. Sites where a sampling unit could not be sampled for some reason (e.g., lack of landowner permission, dry conditions) were excluded from the paired analysis. Some reaches were duplicated in the analysis, as the close proximity of some road crossings caused the upstream reach of one site to essentially be the downstream reach of the next site.

\section{Genetic differentiation}

We extracted DNA from fin-clip samples using DNeasy Blood and Tissue kits (Qiagen, Germantown, MD). We screened variation at 9 loci using primer pairs developed to amplify microsatellite DNA loci in the closely related Phoxinus phoxinus (L.) (Common Minnow): Cto-A-247, LleC-090, BLi-84, and BLi-153 (Dubut et al. 2009a, 2009b, 2010); Lco3 (Turner et al. 2004); Lsou8 (Muenzel et al. 2007); Rhea 20 (Girard and Angers 2006); CypG30 (Vyskocilova et al. 2007); and MFW1 (Crooijmans et al. 1997). We modified polymerase chain reaction amplification protocols from those outlined by Grenier et al. (2013) as needed to promote amplification across species. The PCR protocol was as follows: initial denaturation 94 ${ }^{\circ} \mathrm{C}$ for 3 minutes; 35 cycles of: denaturation at $94{ }^{\circ} \mathrm{C}$ for 1 minute, annealing at 56 ${ }^{\circ} \mathrm{C}$ for 45 seconds, and extension at $72{ }^{\circ} \mathrm{C}$ for 1 minute; and final extension $72{ }^{\circ} \mathrm{C}$ for 5 minutes. We examined amplification products on ethidium bromide-stained gels, and sent those showing clear products in the appropriate size range to Cornell University for DNA fragment-size analysis using an automated DNA sequencer. We used the program Genemarker (Hulce et al. 2011) to score microsatellite fragments. We calculated $F_{\text {ST }}$ using FSTAT v 2.9.4 (Goudet 2005) and tested the significance of $F_{\mathrm{ST}}$ values using a randomization procedure with 1100 permutations, with an adjusted nominal level of significance for $\alpha=0.05$ for multiple comparisons of $\alpha=0.00909$. A fuller examination of population genetic patterning is presented in Bourquin (2020) and in a companion manuscript (Bourquin et al., in press).

IN METHODS, IT $\underline{\text { SAYS } 2}$ UNITS PER SITE (UP AND DOWNSTREAM) ... SO IF 19 TOTAL SITES, WHY NOT 38 SAMPLING UNITS?]

\section{Results}

Clinch Dace were caught in 17 of 29 [??] sampling units and from 11 of 19 [??] sites sampled in 2017. Clinch Dace represented small percentages of total fish caught: $0-7.9 \%$ in the upstream reaches and $0-10.2 \%$ in downstream reaches (Table 1). For estimated density (fish/100 m), the mean was 13.4, median was 6.5, and min-max was 0.5-63.6 (Fig. 2).

Sampling effort for all sampled reaches was sufficient to characterize the populations, as the relationship between species richness and sample length was not significant for $n=17\left(r^{2}=0.0196, P\right.$-value $\left.=0.94\right)$. In addition, the total cumulative richness at 29 out of 30 reaches was achieved in the first of 3 passes.

There were no significant relationships between Clinch Dace presence and canopy cover, conductivity, maximum depth, presence of woody debris, fish density, 
or species richness (Table 2). Clinch Dace abundance was positively related to conductivity (coefficient $=0.0085 ; P=0.03$ ) and not related to other variables (Table 3). A single datum with highest conductivity and population influenced the statistical result. No significant differences were detected in Clinch Dace abundance between upstream and downstream reaches $(t=0.83$, df $=13, P=0.42)$. We removed from analysis 5 of the 19 sites sampled due to access limitation.

We estimated the genetic differentiation metric $F_{\mathrm{ST}}$ among collections from the upstream and downstream reaches of 6 sites with putative barriers to Clinch Dace migration. These sites were Big Lick 1, Big Lick 3, Hart Creek 1, Hart Creek 1/2 ( sites that overlap, as the distance between culverts is less than $200 \mathrm{~m}$; hence, we

Table 1. Percentage (\%) of total fish catch represented by Clinch Dace at each reach sampled and for the total site. $\mathrm{NS}=$ not sampled, NA = fish not counted, $*=$ perched culvert at site.

\begin{tabular}{|c|c|c|c|c|c|}
\hline \multirow[b]{2}{*}{ Site } & \multicolumn{2}{|c|}{ \% Clinch Dace } & \multirow[b]{2}{*}{$\begin{array}{c}\text { Total } \\
\text { \% Clinch Dace }\end{array}$} & \multirow[b]{2}{*}{$\begin{array}{c}\text { Total } \\
\text { fish count }\end{array}$} & \multirow[b]{2}{*}{$\begin{array}{l}\text { Total Clinch } \\
\text { Dace count }\end{array}$} \\
\hline & $\begin{array}{l}\text { Upstream } \\
\text { reach }\end{array}$ & $\begin{array}{l}\text { Downstream } \\
\text { reach }\end{array}$ & & & \\
\hline Hess Creek 2 & 0.0 & 0.0 & 0.0 & 714 & 0 \\
\hline Lewis Creek2 & 0.0 & 0.0 & 0.0 & 1075 & 0 \\
\hline Lewis Creek 3 & 0.0 & 0.0 & 0.0 & 902 & 0 \\
\hline Lewis Creek 4 & 0.5 & 0.0 & 0.3 & 1079 & 3 \\
\hline Jackson Fork 1 & 0.0 & 0.0 & 0.0 & 700 & 0 \\
\hline Jackson Fork 2 & 0.0 & 0.0 & 0.0 & 337 & 0 \\
\hline Big Lick Creek 1 & 3.8 & 4.3 & 4.0 & 2258 & 91 \\
\hline Big Lick Creek 2 & 0.9 & 0.1 & 0.4 & 1393 & 6 \\
\hline Big Lick Creek 3 & 3.2 & 2.3 & 2.4 & 1569 & 38 \\
\hline Big Lick Creek 4 & NS & 1.9 & 1.9 & 573 & 11 \\
\hline Middle Creek 3 & 7.9 & 5.0 & 6.1 & 262 & 16 \\
\hline Hurricane Fork 1 & 4.0 & 4.7 & 4.3 & 1640 & 71 \\
\hline Greasy Creek 1 & 0.0 & 0.3 & 0.2 & 2104 & 5 \\
\hline Greasy Creek 2 & NS & 0.1 & 0.1 & 1281 & 1 \\
\hline Hart Creek 1 & 5.1 & 10.2 & 8.5 & 1557 & 132 \\
\hline Hart Creek $2 *$ & NA & NA & NA & NA & 43 \\
\hline Pine Creek 3 & 0.0 & NS & 0.0 & 1491 & 0 \\
\hline Town Hill Creek 1 & NS & 0.0 & 0.0 & 3134 & 0 \\
\hline Town Hill Creek 2 & 0.0 & NA & 0.0 & NA & 0 \\
\hline
\end{tabular}

Table 2. Logistic regression of Clinch Dace presence/absence and canopy cover, conductivity at site level, maximum depth, presence of woody debris, fish density, and species richness.

\begin{tabular}{lccccc} 
Variable & $n$ & $\beta$-Estimate & Std. Error & $Z$-value & $P$ - value \\
\hline Canopy cover & 27 & 0.0021 & 0.023 & 0.091 & 0.93 \\
Conductivity & 15 & 0.0114 & 0.006 & 1.756 & 0.08 \\
Max depth & 27 & -0.0001 & 0.002 & -0.050 & 0.96 \\
Woody debris & 26 & 2.1208 & 2.533 & 0.837 & 0.40 \\
Fish density & 28 & 0.0122 & 0.313 & 0.039 & 0.97 \\
Richness & 30 & -0.4193 & 0.233 & -1.800 & 0.07 \\
\hline
\end{tabular}


calculated $F_{\mathrm{ST}}$ for the upstream sampling unit of Hart Creek 1 and the only sampling unit on Hart Creek 2), Hurricane Fork, and Middle Creek. Most $F_{\mathrm{ST}}$ values for paired upstream and downstream sites were low (Table 4), varying from 0.002 to 0.031 . However, 2 sets were considerably higher, Middle Creek $3\left(F_{\mathrm{ST}}=0.062\right)$ and Hart Creek $2\left(F_{\mathrm{ST}}=0.213\right)$. None of these $F_{\mathrm{ST}}$ values, however, was significantly different from zero.

\section{Discussion}

The Clinch Dace warrants classification as a rare species within its known range. Rare species categorized as endangered, threatened, or vulnerable often have low

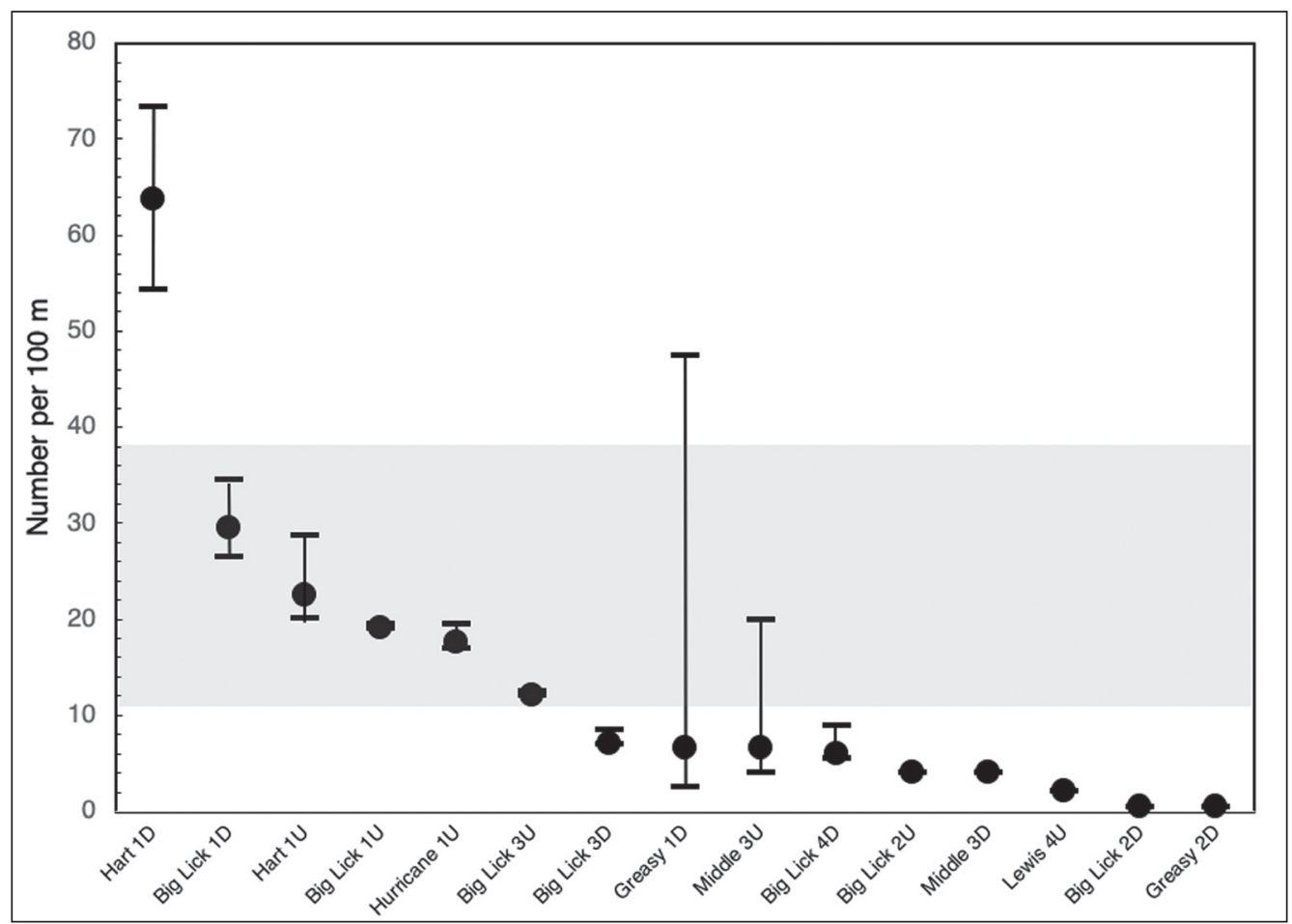

Figure 2. Clinch Dace population estimates by sampling unit standardized to $100 \mathrm{~m}$ of stream length. Shaded area indicates 95\% confidence limits for 22 sites from Moore et al. (2017).

Table 3. Quasi-Poisson regression of Clinch Dace abundance and canopy cover, conductivity, maximum depth, woody debris, fish density, and species richness.

\begin{tabular}{lccccc} 
Variable & $n$ & $\beta$-Estimate & Std. Error & $t$-value & $P$ - value \\
\hline Canopy cover & 27 & 0.0216 & 0.014 & 1.536 & 0.14 \\
Conductivity & 14 & 0.0085 & 0.003 & 2.518 & 0.03 \\
Max depth & 27 & 0.0006 & 0.001 & 0.481 & 0.63 \\
Woody debris & 26 & 1.6077 & 1.356 & 1.177 & 0.25 \\
Fish density & 28 & 0.3201 & 0.343 & 0.932 & 0.36 \\
Richness & 30 & -0.1107 & 0.152 & -0.729 & 0.47 \\
\hline
\end{tabular}


local abundance, small ranges, and specific habitat needs (Pritt and Frimpong 2009). Clinch Dace are present at low rates of occupancy only in small, naturally depauperate streams, and when present, they were less than $5 \%$ of the fish assemblage (Moore et al. 2017, 2018; White and Orth 2014). However, populations persist at sites with extensive fine sediments apparently due in part to nest association with other minnows, Semotilus atromaculatus (Mitchill) (Creek Chub) and Campostoma anomalum Rafinesque (Central Stoneroller) (Hatcher et al. 2017, White and Orth 2014), similar to sister species (Cronnon et al. 2019, Hamed et al. 2008). Nearby sites in larger stream reaches than our sample had higher species richness and few or no Clinch Dace found (White and Orth 2014).

Clinch Dace represented a small proportion of fish abundance in all streams surveyed in 2017. The habitat metrics that we analyzed seem to have little influence on Clinch Dace presence or abundance. It seemed that Clinch Dace mostly inhabited shallow, sandy pools, not gravel riffles, which occurred further downstream. The one positive relationship, between Clinch Dace abundance and conductivity, was counter to a previously observed, weak, negative relationship between Clinch Dace abundance and conductivity (Moore et al. 2018). However, all study sites we sampled had a narrow spectrum of conductivity levels that were below the proposed USEPA water quality criterion for aquatic life (USEPA 2011). Because our sampling sites were targeted to sites of known Clinch Dace presence, conductivity was expected to be at a level tolerable to Clinch Dace. One site, Big Lick Creek 1 Downstream, where both conductivity and abundance were high, drove what we believe was a spurious correlation. It may be that legacy effects of mining that once caused toxicity or higher levels of conductivity eliminated some populations of Clinch Dace, and its current distribution may reflect past habitat disruption.

Clinch Dace abundance was low (13.4 fish per $100 \mathrm{~m}$ ) as compared to previous density estimates (mean $=25$ fish per $100 \mathrm{~m}, 95 \% \mathrm{CI}=11-39$ ) reported for the species (Fig. 1; Moore et al. 2017, 2018). Choice of management alternatives for Clinch Dace restoration depends on genetic divergence in relation to putative barriers to gene flow (Moore et al. 2018). However, $F_{\mathrm{ST}}$ values were not significantly different from zero, indicating no fine-scale barriers to recent gene flow. Recent studies of culvert effects on fish passage and gene flow have focused on trout (Whiteley et al. 2014). Studies of small, non-game fishes have more typically detected a reduction in movement rates in the presence of certain types of culverts (Benton et al.

Table 4. Pairwise $F_{\mathrm{ST}}$ values for Clinch Dace in reaches up- and downstream of putative barriers to migration. $*=$ perched culvert at site. All estimated $P$ values were non-signficant $(P>0.05)$.

\begin{tabular}{lc} 
Site & $F_{\mathrm{ST}}$ \\
\hline Big Lick Creek 1 & 0.002 \\
Big Lick Creek 3 & 0.050 \\
Hart Creek 1 & 0.015 \\
Hart Creek 1/2* & 0.213 \\
Hurricane Fork 1 & 0.031 \\
Middle Creek 3 & 0.062 \\
\hline
\end{tabular}


2008, Warren and Pardew 1998). A single road crossing that had become perched dramatically decreased abundances of other species-Chrosomus cumberlandensis (W.C. Starnes and L.B. Starnes) (Blackside Dace), Etheostoma kennicotti (Putnam) (Stripetail Darter), and Etheostoma saggita (Jordan and Swain) (Arrowhead Darter) - upstream of the culvert since its construction (Eisenhour and Floyd 2013). Eisenhour and Floyd (2013) speculated that stream segments with population losses in times of drought and drying cannot be recolonized by individuals from downstream of the culvert, where the population remains demographically strong. These results collectively suggest that culverts, particularly perched culverts, can contribute to fragmentation and local extirpation of fish populations during periods of drought. With the exception of Hart Creek 2, none of our road crossings were perched culverts and did not disrupt gene flow. Therefore, other priority actions recommended in recovery plans may be more important for Clinch Dace than the mitigation of road crossings (George et al. 2016).

Our findings are relevant to understanding population dynamics of other Chrosomus, which have shared traits of mobility, nest association, and headwater habitat use. Furthermore, Clinch Dace, Blackside Dace, and Laurel Dace occur at low population densities in a limited number of streams (Black et al. 2013, George et al. 2016, McAbee et al. 2013, Moore et al. 2018). Geographic isolation has resulted in widespread extirpation or recruitment failures of minnow species after regional widespread drought (Pennock and Gido 2017, Perkin et al. 2019). Although we did not sample Clinch Dace populations annually, we have noticed variation in summer water level and intermittency related to prevailing groundwater and precipitation over multiple survey years. In these small, variable headwaters, movement of individuals may be critical to long-term population persistence (Albanese et al. 2009) and may thereby decrease chances of inbreeding in small populations.

Blackside Dace have both sedentary and highly mobile individuals (Detar and Mattingly 2013). Movements of Chrosomus erythrogaster (Rafinesque) (Southern Redbelly Dace) fluctuated over time and were influenced by fish size and pool isolation (Walker et al 2013). Emigration of Nocomis leptocephalus (Girard) (Bluehead Chub) increased with intermittency, and Chrosomus oreas Cope (Mountain Redbelly Dace) colonized upstream reaches rapidly after flow increases (Albanese et al. 2004). Mobility of individuals may be a shared trait in Chrosomus species to permit rapid recovery after disturbance. Another shared trait in Chrosomus species is nest association with other nest-building minnows (Hatcher et al. 2017). Nest-building Creek Chub and Campostoma spp. (stonerollers) persist through periods of drought and intermittency by using pools as refugia and rapidly moving upstream after drought (Hodges and Magoulick 2011, Walker and Adams 2016). Consequently, movements of Chrosomus individuals in concert with Creek Chub would be adaptive. Therefore, efforts to prevent construction of impassable barriers are warranted in streams occupied by rare Chrosomus spp. In populations of rare Chrosomus spp. not fragmented by road crossings, active or passive stream restorations aimed at improving or protecting habitat may be prudent management strategies (Moore et 
al. 2018), and translocations within tributaries should not be of genetic concern (George et al. 2009).

\section{Acknowledgments}

This research was funded through a US Fish and Wildlife Service State Wildlife Grant managed through the Virginia Department of Game and Inland Fisheries. All work was in accordance with collection permits issued by Virginia Department of Game and Inland Fisheries and protocol 16-188FIW, approved by the Virginia Tech Institutional Animal Care and Use Committee. Special thanks go to Miluska Hyde, Sheila Harris, Corbin Hilling, Kaitlin Hanak, Chanz Hopkins, and Mike Pinder. The participation of coauthors D.J. Orth, E.M. Hallerman, and D.F. Stauffer was supported in part by the US Department of Agriculture through the National Institute of Food and Agriculture Program. The manuscript was improved by comments and suggestions of the manuscript editor and reviewers.

\section{Literature Cited}

Albanese, B., P.L. Angermeier, and S. Darai-Raj. 2004. Ecological correlates of fish movements in a network of Virginia streams. Canadian Journal of Fisheries and Aquatic Sciences 61:857-869.

Albanese, B., P.L. Angermeier, and J.T. Peterson. 2009. Does mobility explain variation in colonisation and population recovery among stream fishes? Freshwater Biology 54:1444-1460.

Alo, D. and T.E. Turner. 2005. Effects of habitat fragmentation on effective population size in the endangered Rio Grande Silvery Minnow. Conservation Biology 19(4):1138-1148.

Benton, P.D., W.E. Ensign, and B.J. Freeman. 2008. The effect of road crossings on fish movement in small Etowah Basin streams. Southeastern Naturalist 7(2):301-310.

Black, T.R., J.E. Detar, and H.T. Mattingly. 2013. Population densities of the threatened Blackside Dace, Chrosomus cumberlandensis, in Kentucky and Tennessee. Southeastern Naturalist 12(Special Issue 4):6-26.

Bourquin, R.M. 2020. Population fragmentation and genetic diversity of Chrosomus sp. cf. saylori (Clinch Dace). M.Sc. Thesis. Virginia Polytechnic Institute and State University, Blacksburg, VA. Available online at http://hdl.handle.net/10919/96757. [PROVIDE DATE ACCESSED]. 91 pp.

Bourquin, R., E.M. Hallerman, M.J. Moore, and D.J. Orth. In press. Conservation genetics of Clinch Dace, Chrosomus sp. cf. saylori. [PROVIDE JOURNAL NAME].

Briggs, A.S. and T.L. Galarowicz. 2013. Fish passage through culverts in central Michigan warmwater streams. North American Journal of Fisheries Management 33(3):652-664.

Cronnon, C.T., M. Harris, B. Kuhajda, and H. Klug. 2019. Behavior of Chrosomus saylori (Laurel Dace) during the breeding season. Southeastern Naturalist 18(3):373-380.

Crooijmans, R.P.M.A, V.A.F Bierbooms, J. Komen, J.J. Van der Poel, and M.A.M. Groenen. 1997. Microsatellite markers in Common Carp (Cyprinus carpio L.). Animal Genetics 28:129-134.

Daubenmire, R., and J.B. Daubenmire. 1968. Forest vegetation of eastern Washington and northern Idaho. Technical Bulletin 60. Washington Agricultural Experiment Station, Washington State University, Pullman, WA. 104 pp.

Detar, J.E., and H.T. Mattingly. 2013. Movement patterns of the threatened Blackside Dace, Chrosomus cumberlandensis, in two southeastern Kentucky watersheds. Southeastern Naturalist 12(Special Issue 4):64-81. 
Dubut V., J.F. Martin, C. Costedoat, R. Chappez, and A. Giles. 2009a. Isolation and characterization of polymorphic microsatellite loci in the freshwater fishes Telestes souffia and Telestes muticellus (Teleostei: Cyprinidae). Molecular Ecology Resources. 9:1001-1005.

Dubut V., J.F. Martin, A. Giles, J. van Houdt, R. Chappez, and C. Costedoat. 2009b. Isolation and characterization of polymorphic loci for the dace complex: Leuciscus leuciscus (Teleostei: Cyprinidae). Molecular Ecological Resources. 9:1179-1183.

Dubut V., M. Sinama, J.F. Martin, E. Meglecz, J. Fernandez, R. Chappez, A. Giles, and C. Costedoat. 2010. Cross-species amplification of 41 microsatellites in European cyprinids: A tool for evolutionary population genetics and hybridization studies. BMC Research Notes 3:135.

Edge, C.B., M.J. Fortin, D.A. Jackson, D. Lawrie, L. Stanfield, and N. Shrestha. 2017. Habitat alteration and habitat fragmentation differently affect beta diversity of stream fish communities. Landscape Ecology 32:647-662.

Eisenhour, D.J., and M.A. Floyd. 2013. A culvert acts as a barrier to Blackside Dace (Chrosomus cumberlandensis) movements in Lick Fork, Kentucky. Southeastern Naturalist 12:82-91.

George, A.L., B.R. Kuhajda, J.D. Williams, M.A. Cantrell, P.L. Rakes, and J.R. Shute. 2009. Guidelines for propagation and translocation for freshwater fish conservation, Fisheries 34:529-545.

George, A.L., B.R. Kuhajda, and D.A. Neely. 2016. Recovery plan for the Laurel Dace (Chrosomus saylori). US Fish and Wildlife Service, Atlanta, GA. 63 pp.

Girard, P., and B. Angers. 2006. Characterization of microsatellite loci in Longnose Dace (Rhinichthys cataractae) and interspecific amplification in five other Leusiscinae species. Molecular Ecology Notes 6:69-71.

Goudet, J. 2005. FSTAT v 2.9.4. Available online at https://www2.unil.ch/popgen/softwares/fstat.htm.

Grenier, R., C. Costedoat, R Chappaz, and V. Dubut. 2013. Two multiplexed sets of 21 and 18 microsatellites for Phoxinus phoxinus (L.) and Gobio gobio (L.) developed by crossspecies amplification. European Journal of Wildlife Research 59:291-297.

Guy, T.J., R.E. Gresswell, and M.A. Banks. 2008. Landscape-scale evaluation of genetic structure among barrier-isolated populations of coastal Cutthroat Trout (Oncorhynchus clarkii clarkii). Canadian Journal of Fisheries and Aquatic Sciences. 50:1749-1762.

Hallerman, E. 2003. Coadaptation and outbreeding depression. Pp. 239-259, In E.M. Hallerman (Ed.). Population Genetics: Principles and Applications for Fisheries Scientists. American Fisheries Society, Bethesda, MD. 475 pp.

Hamed, M.K., F.J. Alsop III, and T.F. Laughlin. 2008. Life-history traits of the Tennessee Dace (Phoxinus tennesseensis) in northeast Tennessee. American Midland Naturalist 160(2):289-299.

Hatcher, H.R., M.J. Moore, and D.J. Orth. 2017. Spawning observations of Clinch Dace: Comparison of Chrosomus spawning behavior. American Midland Naturalist 177:318-326.

Hodges, S.W., and D.D. Magoulick. 2011. Refuge habitats for fishes during seasonal drying in an intermittent stream: Movement, survival, and abundance of three minnow species. Aquatic Sciences 73:513-522.

Hulce, D., X. Li, and T. Snyder-Leiby. 2011. GeneMarker genotyping software: Tools to increase the statistical power of DNA fragment analysis. Journal of Biomolecular Techniques 22 (Suppl):S35-S36. 
Kazyak, P. 2001. Maryland biological stream survey sampling manual. Monitoring and Non-Tidal Assessment Division, Maryland Department of Natural Resources, Annapo[COULD lis, MD. 83 pp.

NOT FIND Lazorchak, J.M., D.J. Klemm, and D.V. Peck (Eds.). 1998. Environmental monitoring and A REFERENCE TO LAZORCHAK ET AL. 1998. EITHER INSERT REF OR DELETE CITATION LISTING.] assessment program - surface waters: Field operations and methods for measuring eco$\underline{\text { logical conditions of wadeable streams. EPA/620/R-94/004F. US Environmental Protec- }}$ tion Agency, Washington, DC. 310 pp.

Lyons, J. 1992. The length of stream to sample with a towed electrofishing unit when fish species richness is estimated. North American Journal of Fisheries Management 12:198-203.

Maitland, B.M., M. Poesch, A.E. Anderson, and S.N. Pandit. 2016. Industrial road crossings drive changes in community structure and instream habitat for freshwater fishes in the boreal forest. Freshwater Biology 61:1-8.

McAbee, K.T., N.P. Nibbelink, T.D. Johnson, and H.T. Mattingly. 2013. Informing recovery management of the threatened Blackside Dace, Chrosomus cumberlandensis, using a Bayesian-belief network model. Southeastern Naturalist 12(Special Issue 4):143-161.

Moore, M.J., E.M. Hallerman, and D.J. Orth. 2017. Densities and population sizes of Clinch Dace Chrosomus sp. cf. saylori in the upper Clinch River basin in Virginia. Copeia 105:92-99.

Moore, M.J, E.M. Hallerman, and D.J. Orth. 2018. Multi-metric conservation assessment for the imperiled Clinch Dace. Southeastern Fishes Council Proceedings 58:31-56

Morita, K., and S. Yamamoto. 2002. Effects of habitat fragmentation by damming on the persistence of stream-dwelling charr populations. Conservation Biology 16:1318-1323.

Muenzel, F.M., M. Sanetra, W. Salzburger, and A. Meyer. 2007. Microsatellites from the vairone Leuciscus souffia (Pisces: Cyprinidae) and their application to closely related species. Molecular Ecology Notes 7:1048-1050.

Nislow, K.H., M. Hudy, B.H. Letcher, and E.P. Smith. 2011. Variation in local abundances and species richness of stream fishes in relation to dispersal barriers: Implications for management and conservation. Freshwater Biology 56:2135-2144.

Pennock, C.A., and K.B. Gido. 2017. Collapsing range of an endemic Great Plains minnow, Peppered Chub Macrhybopsis tetranema. American Midland Naturalist 177:57-68.

Perkin, J.S., and K.B. Gido. 2012. Fragmentation alters stream fish community structure in dendritic ecological networks. Ecological Applications 22(8):2176-2187.

Perkin, J.S., K.B. Gido, K.H. Costigan, M.D. Daniels, and E.R. Johnson. 2015. Fragmentation and drying ratchet down Great Plains stream fish diversity. Aquatic Conservation 25:639-655

Perkin, J.S., T.A. Starks, C.A. Pennock, K.B. Gido, G.W. Hopper, and S.C. Hedden. 2019. Extreme drought causes fish recruitment failure in a fragmented Great Plains riverscape. Ecohydrology 12(6):e2120. https://doi.org/10.1002/eco.2120

Pritt, J.J., and E.A. Frimpong. 2009. Quantitative determination of rarity of freshwater fishes and implications for imperiled species designations. Conservation Biology 245:1249-1258.

R Core Team. 2017. R: A language and environment for statistical computing. [VERSION?]. R Foundation for Statistical Computing, Vienna, Austria. Available online at https://www.R-project.org/.

Roberts, J.H., P.L. Angermeier, and E.M. Hallerman. 2013. Distance, dams, and drift: What structures populations of an endangered, benthic stream fish. Freshwater Biology 58:2050-2064. 
Skelton, C. E. 2007. Distribution and status of Blackside Dace (Phoxinus cumberlandensis) and Clinch Dace (Phoxinus sp. cf. saylori) in the upper Clinch River system, Virginia. Final Report to Virginia Department of Game and Inland Fisheries, Richmond, VA. 48 pp..

Tan, M., and J.W. Armbruster. 2018. Phylogenetic classification of extant genera of fishes of the order Cypriniformes (Teleostei: Ostariophysi). Zootaxa 4476(1):6-39

Templeton, A.R., H. Hemmer, G. Mace, U.S. Seal, W.M. Shields, and D.S. Woodruff. 1986. Local adaptation, coadaptation, and population boundaries. Zoo Biology 5:115-125.

Turner, T.F., T.E. Dowling, R.E. Broughton, and J.R. Gold. 2004. Variable microsatellite markers amplify across divergent lineages of cyprinid fishes (subfamily Leusiscinae). Conservation Genetics 5:279-281.

United States Environmental Protection Agency (USEPA). 2011. A field-based aquatic life benchmark for conductivity in central Appalachian streams. US Environmental Protection Agency, EPA/600/R-10/023F, Washington, DC. 276 pp.

Van Deventer, J.S., and W.S. Platts. 1989. Microcomputer software system for generating population statistics from electrofishing data: User's guide for Microfish 3.0. General Technical Report INT 254. US Department of Agriculture, Forest Service, Intermountain Research Station, Ogden, UT. 29 pp.

Vyskocilova, M., A. Simkova, and J.F. Martin. 2007. Isolation and characterization of microsatellites in Leuciscus cephalus (Cypriniformes, Cyprinidae) and cross-species amplification within the Family Cyprinidae. Molecular Ecology Notes 55:627-629.

Walker, R.H., and G.L. Adams. 2016. Ecological factors influencing movement of Creek Chub in an intermittent stream of the Ozark Mountains, Arkansas. Ecology of Freshwater Fish 25:190-202.

Walker, R.H., G.L. Adams, and S.R. Adams. 2013. Movement patterns of Southern Redbelly Dace, Chrosomus erythrogaster, in a headwater reach of an Ozark stream. Ecology of Freshwater Fish 22:216-227.

Warren, M.L., and M.G. Pardew. 1998. Road crossings as barriers to small-stream fish movement. Transactions of the American Fisheries Society 127:637-644.

White, S.L., and D.J. Orth. 2013. Ontogenetic and comparative morphology of Clinch Dace (Chrosomus sp. cf. saylori). Copeia 2013:750-756.

White, S.L., and D.J. Orth. 2014. Distribution and habitat correlates of Clinch Dace (Chrosomus sp. cf. saylori) in the upper Clinch River watershed. American Midland Naturalist 171:311-320.

Whiteley, A.R., J.A. Coombs, M. Hudy, Z. Robinson, A.R. Colton, K.H. Nislow, and B.H. Letcher. 2013. Fragmentation and patch size shape genetic structure of Brook Trout populations. Canadian Journal of Fisheries and Aquatic Sciences 70:678-688.

Whiteley, A.R., J.A. Coombs, B.H. Letcher, and K.H. Nislow. 2014. Simulation and empirical analysis of novel sibship-based genetic determination of fish passage. Canadian Journal of Fisheries and Aquatic Sciences 71:1667-1679.

Yamamoto, S., K. Morita, L. Koizumi, and K. Maekawa. 2004. Genetic differentiation of White-spotted Charr (Salvelinus leucomaenis) populations after habitat fragmentation: Spatial-temporal changes in gene frequencies. Conservation Genetics 5:529-538. 